\title{
TVRI STASIUN RIAU KEPRI: STUDI KASUS KEBERADAAN MEDIA MASSA DALAM PEMBANGUNAN PROVINSI RIAU (1998-2018)
}

\author{
Raiza Nanda Pratama, Ahmal, Asyrul Fikri. \\ Program Studi Pendidikan Sejarah, FKIP, Universitas Riau \\ Email: pratamaraiza123@gmail.com, ahmal@lecturer.unri.ac.id, \\ asyrul.fikri@lecturer.unri.ac.id
}

Abstract: Today, mass media development is growing rapidly, this can be seen in the variety of choices for people to get news, entertainment and knowledge. One of the growing mass media is television. Television plays a very important role in development. The purpose of this document is: To understand the initial process of the formation and development of the Riau Kepri Station of the Television Republic of Indonesia (TVRI) and the role of the Riau Kepri Station of the Television Republic of Indonesia (TVRI) as a mass media in development. Province of Riau in the field of Social and Economic, Education and Culture. The research method that will be used in this research is the historical method. The television era in Riau province started since 1977 when the TVRI Relay Station Tower was built at that time. The development of TVRI Riau Kepri Station began to appear in 1999, where in 1999 TVRI Riau Station was able to broadcast locally for the first time, exactly in January. The role of TVRI Riau Kepri Station served as a tool used to disseminate information about the public's development. in the province of Riau

Keywords: History, development, TVRI Riau Kepri Station

\begin{abstract}
Abstrak: Dewasa ini perkembangan media massa sangatlah berkembang dengan pesat hal ini terlihat dari beragamnya pilihan bagi masyarakat untuk mendapatkan berita, hiburan, maupun pengetahuan. Salah satu diantara media massa yang berkembang ini adalah televisi. Televisi mempunyai peran yang sangat penting dalam pembangunan. tujuan dari penulisan ini adalah: Untuk mengetahui proses awal pembentukan dan perkembangan Televisi Republik Indonesia (TVRI) stasiun Riau Kepri serta Untuk mengetahui peranan Televisi Republik Indonesia (TVRI) stasiun Riau Kepri sebagai media massa dalam pembangunan di Provinsi Riau dalam bidang Sosial dan Ekonomi, Pendidikan dan Kebudayaan. Metode penelitian yang akan digunakan dalam penelitian ini adalah metode sejarah.. Era pertelevisian di Provinsi Riau sudah dimulai dari tahun 1977 dimana pada saat ini dibangunlah menara stasiun relai TVRI. Perkembangan TVRI Stasiun Riau Kepri mulai terlihat pada 1999, dimana pada 1999 TVRI Stasiun Riau sudah dapat bersiaran secara lokal untuk pertama kali tepatnya pada bulan Januari. Peranan TVRI Stasiun Riau Kepri bertugas sebagai alat yang digunakan untuk menyebarluaskan informasi mengenai pembangunan kekhalayak umum. di Provinsi Riau
\end{abstract}

Keywords: Sejarah, Perkembangan, TVRI Stasiun Riau Kepri

Jurnal PENDIDIKAN SEJARAH 77 Vol. 10 No. 1 Januari 2021 


\section{PENDAHULUAN}

Dewasa ini perkembangan media massa sangatlah berkembang dengan pesat hal ini terlihat dari beragamnya pilihan bagi masyarakat untuk mendapatkan berita, hiburan, maupun pengetahuan. Media masa merupakan sarana yang sangat berpengaruh bagi kehidupan manusia. Media massa secara sadar mengembangkan nilai dan norma berdasarkan visi dan misi yang diembannya. Setidaknya ada empat fungsi media massa atau komunikasi massa yang dapat kita sederhanakan yaitu menyampaikan infromasi (to inform), mendidik (to educate), menghibur (to entertain) dan mempengaruhi (to influence) (Tahrun, Houtman, \& Nasir, 2019:51-52)

Media massa adalah media komunikasi dan informasi yang melakukan penyebaran informasi secara massal dan dapat diakses oleh masyarakat secara massal pula. Informasi massa adalah informasi yang diperuntukan kepada masyarakat secara massal, bukan media yang boleh dikonsumsi oleh pribadi (Fuad Abbas, Saleh Pasallo. 2013:91). Media massa dalam fungsi diyakini mempunyai kekuataan yang dahsyat untuk memengaruhi sikap dan perilaku masyarakat. Bahkan media massa bisa mengarahkan masyarakat seperti apa yang akan dibentuk di masa yang akan datang. Media massa mampu mengarahkan, membimbing, dan memengaruhi kehidupan di masa kini dan masa datang (Romli, 2016:45)

Salah satu diantara media massa yang berkembang ini adalah televisi. Dalam penemuan televisi, terdapat banyak pihak yang terlibat dalam pembuatan televisi baik secara perorangan maupun perusahaan. Istilah televisi pertama kali dikemukakan oleh Constatin Perskly dari Rusia pada 1900 
dalam acara pameran teknologi dunia di Paris. Lalu Pada 1925, sejarah perkembangan televisi menapaki babak baru ketika John Logie Baird yang berkebangsaan Skotlandia memperlihatkan televisi kepada umum untuk pertama kalinya. Perkembangan Televisi pun sangat pesat. Pada perkembangannya televisi sering digunakan dalam bentuk penyiaran atau siaran televisi, yang di buat berdasarkan sistem penyiaran radio yang dikembangkan pada 1920 an.

Munculnya siaran televisi di berbagai negara memiliki waktu yang berbeda-beda antara satu sama lain, seperti Amerika Serikat yang telah memiliki siaran televisi pada 1942 yaitu siaran NBC, CBS. Negara yang pertama mengawali siaran televisi di Eropa dengan penayangan upacara penobatan raja Goerge VI pada 1937. Selain Inggris, Jerman memulai siaran televisi secara komersial pada tahun 1948 dan Italia pada 1953. Sedangkan dikawasan Asia, Indonesia bukanlah negara pertama yang mengawali pertelevisian. Pada 1953, Jepang telah melakukan siaran televisi untuk pertama kali yang diikuti oleh Filipina pada tahun yang sama. Demikian pula Thailand memiliki teknologi pertelevisian sejak 1955. Sedangkan Republik Rakyat China baru melakukannya 1962, tahun yang sama dengan Indonesia (Istanto, 1999:95).

Di Indonesia kehadiran media televisi mulai difikirkan setelah Indonesia terpilih menjadi tuan rumah penyelenggaraan Asian Games IV yang dibuka pada 24 Agustus 1962. Sebelumnya pada 1961, Menteri penerangan masa itu yakni R. Maladi sebagai penggagas utama berharap agar kehadiran media televisi di pesta olahraga dapat dipergunakan sebagai langkah awal dari 
pembangunan media televisi nasional. Usulan tersebut di dukung oleh Presiden Soekarno yang memutuskan untuk memasukannya dalam pembangunan sarana Asian Games IV di bawah pimpinan Letnan Jendral Suprayogi. Keputusan itu diwujudkan melalui Surat Keputusan Menteri Penerangan No. 20/ SKM/ 1961 tentang pembentukan Panitia Persiapan Televisi (P2T) pada 25 Juli 1961 (Halim, 2019:14). Setelah stasiun dan pemancar dari Televisi Republik Indonesia selesai dibangun pada 22 Agustus 1961, media televisi yang disebut dengan Televsi Republik Indonesia (TVRI) melakukan tugas pertamanya sebagai siaran percobaan disiarkan pada tanggal 17 Agustus 1962 yaitu berupa siaran khusus liputan tentang upacara peringatan detik-detik Proklamasi Kemerdekaan Republik Indonesia.

Setelah melewati masa siaran percobaan, akhirnya TVRI melakukan tugasnya untuk menyiarkan Asian Games IV dari 24 Agustus 1962 sampai 4 September 1962. Pada saat itu siaran yang dilakukan terbatas hanya untuk Kota Jakarta Raya dan sekitaranya. Baru pada tanggal 11 Oktober 1962 studio TVRI diresmikan. Dalam perkembangannya TVRI mengalami sejumlah perubahan dan perkembangan baik status maupun perkembangannya di daerah-daerah yang ada di Indonesia, baru pada 1964 mulailah dirintis pembangunan stasiun daerah yang dimulai dari Stasiun Yogyakarta yang berturut-turut diikuti dengan stasiun Medan, Surabaya Makassar, Manado, Denpasar, Samarinda dan lainnya. Hingga saat ini terdapat 30 stasiun daerah yang tersebar di seluruh Indonesia, termasuk salah satunya adalah stasiun TVRI daerah Riau. 
Era pertelevisian di Provinsi Riau sudah dimulai dari tahun 1977 dimana pada saat ini dibangunlah menara stasiun relai TVRI yang umumnya disebut stasiun pemancar tv atau stasiun transmisi yaitu suatu tempat atau lokasi yang berguna untuk memancarkan siaran televisi di wilayah yang akan dipancarkan, ditahun 1998 di resmikanlah stasiun produksi di Pekanbaru. TVRI SP Pekanbaru di resmikan oleh Menteri Penerangan pada saat itu yakni Muhammad Yunus Yosfiah pada 3 November 1998. TVRI SP Pekanbaru melakukan siaran lokal perdana pada 1 Ramadhan 1419 Hijriyah yaitu tepatnya pada bulan Januari 1999 menyiarkan Azan Magrib, kemudian dilanjutkan penayangan selama satu jam. Pada 2003 frekuensi siaran ditingkatkan menjadi tiga jam penayangan setiap harinya yaitu pada pukul 16:00-19:00 WIB, pada 2004 TVRI Pekanbaru berganti nama menjadi TVRI stasiun Riau Kepri dengan jam tayang masih selama tiga jam setiap harinya.

Pada tanggal 1 April 2007 program siaran TVRI stasiun Riau Kepri meningkatkan durasi penayangan selama empat jam yaitu dimulai dari pukul 15:00-19:00 WIB dan di 2010 siaran TVRI Riau Kepri yang telah menggunakan siaran digital bersiaran selama sembilan jam setiap harinya, dimulai dari pukul 13:00-22.00 WIB. Awal 2018 seiring dengan pergantian manajemen atas TVRI Pusat, maka siaran lokal daerah dipersingkat dimulai pada pukul 14:00-18:00 WIB. TVRI Riau Kepri memiliki jangkauan meliputi Kota Pekanbaru, Kabupaten Kampar, Kabupaten Siak, sebagian Dumai, sebagian Kuantan Singingi, sebagian Indragiri Hulu, sebagian Kabupaten Pelalawan, sebagian Kabupaten Pelalawan, sebagian Rokan Hulu. 
Dalam perkembangannya media televisi mempunyai peran yang sangat penting dalam pembangunan. Pembangunan adalah usaha mewujudkan kesejahteraan masyarakat (Oetama, 2001:280). Pembangunan dilaksanakan dengan tujuan untuk mewujudkan masyarakat adil dan makmur yang merata baik secara material maupun secara spiritual. Pembangunan meliputi segi kehidupan politik, ekonomi, sosial, budaya pembangunan dapat berhasil apabila pembangunan itu melibatkan partisipasi seluruh rakyat Indonesia. Dalam pelaksanaan pembangunan dibutuhkanlah sarana informasi yang jelas. Apabila informasi yang dilaksanakan berjalan dengan jelas dan benar maka pelaksanaan pembangunan akan mendapat dukungan dari masyarakat, sehingga pelaksanaan komunikasi melalui media massa salah satunya adalah televisi sangat penting dan diperlukan.

TVRI stasiun Riau Kepri sebagai salah satu lembaga penyiaran publik (LPP) yang berperan aktif dalam memenuhi kebutuhan informasi dan ikut serta sebagai media massa yang memberikan informasi pembangunan yang ada di Provinsi Riau baik dalam bidang Sosial, Ekonomi, Pendidikan dan Kebudayan. Untuk menghadirkan informasi pembangunan kepada masyarakat mengenai pembangunan Provinsi Riau, TVRI stasiun Riau Kepri menghadirkan berbagai macam inovasi serta program-program acara yang berperan aktif sebagai wadah infromasi masyarakat. Melalui beberapa program tayangannya, TVRI stasiun Riau Kepri berupaya memberikan ruang dalam upaya penyebarluasan informasi dari berbagai inovasi dalam pembangunan Provinsi Riau. Dengan demikian TVRI stasiun Riau Kepri sebagai media yang netral dan berimbang turut mengambil pernanan dalam 
rangka berkontribusi mendukung upaya-upaya pembangunan daerah seperti mendukung program sosial, ekonomi, pendidikan dan kebudayaan.

Dengan menyadari pentingnya mengetahui sejarah, perkembangan dan peranan dari TVRI stasiun Riau dalam pembangunan di Provinsi Riau. Maka dari itu penulis tertarik melakukan penelitian mengenai "Televisi Republik Indonesia (TVRI) Stasiun Riau Kepri: Studi Kasus Keberadaan Media Massa Dalam Pembangunan Provinsi Riau (1998-2018)". Adapun tujuan dari penelitian yaitu: (1) Bagaimana proses awal pembentukan Televisi Republik Indonesia (TVRI) stasiun Riau Kepri (2) Bagaimana perkembangan Televisi Republik Indonesia (TVRI) stasiun Riau Kepri (1998-2018) (3) Bagaimana peranan Televisi Republik Indonesia (TVRI) stasiun Riau Kepri sebagai media massa dalam pembangunan sosial dan ekonomi, pendidikan dan kebudayaan di Provinsi Riau.

\section{METODE}

Metode penelitian yang akan digunakan dalam penelitian ini adalah metode sejarah. Metode sejarah adalah seperangkat aturan dan prinsip sistematis untuk mengumpulkan sumber-sumber sejarah secara efektif, menilainya secara kritis, dan mengajukan sintesis dan hasil-hasil yang dicapai dalam bentuk (Abdurahman , 2007:53). Sedangkan Menurut Gottschalk dalam Haidar dan Nurgaya (2016:5) metode sejarah adalah proses menguji dan menganalisis scara kritik rekaman dan peninggalan masa lampau. Dengan demikian, diperlukan rekontruksi yang imajinatif daripada masa lampau berdasarakan data yang diperoleh dengan menempuh proses yang disebut 
dengan historiografi (penulisan sejarah). Selain itu metode sejarah dapat juga diartikan sebagai seperangkat aturan dan prinsip sistematis untuk mengumpulkan sumber-sumber sejarah secara efektif, menilainya secara kritis, dan mengajukan sintesis dan hasil-hasil yang dicapai dalam bentuk tertulis (Herdiani, 2016:33) Dalam penelitian sejarah terdapat empat langkahlangkah dari metode sejarah yaitu: (1) Heuristik (2) Verifikasi (3) Interpretasi (4) Historiografi.

Penelitian ini akan dilakukan di beberapa tempat yang memiliki data yang dibutuhkan oleh peneliti antara lain yaitu kantor TVRI satsiun Riau Kepri di Jalan Durian, Labuh Baru Timur, Kecamatan Payung Sekaki, Kota Pekanbaru. Provinsi Riau. Selain itu peneliti juga akan mencari data-data yang tersedia diluar TVRI stasiun Riau Kepri seperti Perpustakaan wilayah Riau, Perpustakan Kota Pekanbaru, Perpustakaan UNRI, Arsip Daerah Riau dan beberapa tempat lainnya.

\section{HASIL DAN PEMBAHASAN}

\section{Proses Awal Pembentukan Televisi Republik Indonesia (TVRI) Stasiun}

\section{Riau Kepri.}

Provinsi Riau yang memiliki karakteristik yang unik dimana hal ini disebabkan karena letak geografis dari Provinsi Riau yang terletak sangat strategis. Provinsi Riau terletak ditengah-tengan pulau Sumatera bagian utara, selain itu Provinsi Riau juga berhadapan langsung dengan jalur perdagangan internasional dan Provinsi Riau juga berbatasan langsung dengan negaranegara ASEAN lainnya. Dengan adanya potensi-potensi yang sangat besar tersebut maka diperlukanlah pengembangan-pengembangan diberbagai 
bidang dan juga penyebaran informasi-informasi menganai potensi-potensi yang ada di Provinsi Riau melalui media-media massa. Seperti surat kabar, radio dan termasuk salah satu diantaranya melalui siaran televisi. Era pertelevisian di Provinsi Riau sudah dimulai dari tahun 1977 dimana pada saat ini dibangunlah menara stasiun relai TVRI yang umumnya disebut stasiun pemancar tv atau stasiun transmisi yaitu suatu tempat atau lokasi yang berguna untuk memancarkan siaran televisi di wilayah yang akan dipancarkan. Stasiun relai televisi ini berlokasi di Jalan Durian No. 24 Labuh Baru Timur, Kota Pekanbaru.

Pembangunan stasiun relai TVRI di Riau yang ada di daerah dibangun secara bertahap, mulai dibangun antara lain stasiun relai Batam, Natuna, Dabo Singkep, Tarempa, Sungai Pakning, Pulau Kijang, Siak, Dumai, Pasir Pangaraian, Baserah, Tembilahan, Selat Panjang. Dengan harapan melalui adanya stasiun relai atau sektor-sektor ini siaran TVRI Nasional pada saat itu sudah dapat diterima oleh masyarakat yang ada di daerah-daerah terutama daerah-daerah terpencil dan juga perbatasan dengan negara tetangga Barulah pada 1998 Riau memiliki stasiun penyiaran TVRI, dimana stasiun penyiaran ini merupakan peningkatan dari awalnya merupakan stasiun relay. pada tanggal 3 November 1998. Diresmikanlah TVRI Stasiun Riau Kepri yang pada saat itu bernama Stasiun Produksi Pekanbaru. Stasiun ini diresmikan oleh Bapak Mhd. Yunus yang saat itu menjabat sebagai Menteri Penerangan Republik Indonesia. Gedung TVRI Stasiun Produksi Pekanbaru terletak di Jalan Pramuka Ujung No. 2 Kecamatan Rumbai Pesisir, Kota Pekanbaru. Stasiun produksi pekanbaru sendiri merupakan stasiun yang terakhir 
berdasarkan urutan peresmian TVRI yang ada di Pulau Sumatera (Budi Rianto,2021)

\section{Perkembangan Televisi Republik Indonesia (TVRI) Stasiun Riau Kepri} 1998-2018

pembangunan untuk Stasiun produksi Riau Kepri mulai pada 1995 dan barulah TVRI Stasiun Riau Kepri diresmikan pada tanggal 3 November 1998 oleh Menteri Penerangan pada saat itu yaitu Mhd. Yunus. TVRI Stasiun Riau Kepri yang ketika itu masih bernama TVRI Stasiun Produksi Pekanbaru. Pada awalnya TVRI Stasiun Pekanbaru pada saat itu hanya melakukan produksi siaran yang mana siaran yang telah diproduksi di Stasiun Pekanbaru dikirim ke TVRI Pusat di Jakarta, dan barulah disiarkan kembali melalui TVRI Pusat.. baru tahun 1999 tepatnya pada bulan Januari. TVRI Stasiun Produksi Pekanbaru melaksanakan uji coba siaran pertama yaitu penayangan secara playback Azan maghrib untuk wilayah Kota Pekanbaru dan sekitarnya, yang mana siaran tersebut juga bertepatan dengan bulan Ramadhan 1419 H. Selain uji coba melalui penayangan Azan Maghrib TVRI Stasiun Produksi Pekanbaru juga melakukan penayangan selama 1(satu) jam yaitu berupa program berita (Suardi Camong, 2021).

\section{Perkembangan Televisi Republik Indonesia (TVRI) Stasiun Riau Kepri 2000-2001}

Diawal 2000 TVRI Stasiun Produksi Pekanbaru dapat melaksanakan siaran langsung dari Ruang Kuning Pendopo Gubernur Riau dimana acara tersebut berupa "Penyambutan Malam Tahun Baru" yang dilakukan seluruh oleh kerabat kerja TVRI Stasiun Produksi Pekanbaru. Seiring berjalannya waktu TVRI Stasiun Produksi Pekanbaru terus meningkatkan produksi acara, 
pada bulan April 2000 TVRI Stasiun Produksi Pekanbaru sudah dapat memproduksi sinetron drama pendek atau serial mini seri yang berjudul "Telatah Melayu" dan "Keluarga Mak Ngah". Ditahun 2000 tepatnya tanggal 7 Juni 2000 TVRI Stasiun Produksi Pekanbaru berubah status dari Stasiun Produksi Pekanbaru berubah menjadi PERJAN (Perusahaan Jawatan) berdasarkan Peraturan Pemerintah Nomor 36 Tahun 2000 tentang pendirian Perusahaan Jawatan Televisi Republik Indonesia. setelah diterbitkannya Peraturan Pemerintah ini, maka TVRI Stasiun Produksi Pekanbaru berubah manjadi Perusahaan Jawatan (PERJAN) TVRI Stasiun Pekanbaru (Muhyin, 2021).

Dengan adanya peraturan pemerintah ini juga membuat TVRI memperoleh kejelasan hukum yakni sebagai perusahaan jawatan yang bertugas untuk menyelenggarakan kegiatan penyiaran televisi sesuai dengan prinsip-prinsip televisi publik, independen, netral, mandiri dan program siarannya berorientasi kepada masyarakat dan tidak semata-mata mencari keuntungan, dan menyelenggarakan kegiatan usaha jasa penyiaran publik dalam berbagai bidang bidang pendidikan, dan hiburan serta lainnya yang dilakukan dengan benar-benar baik. Setelah pergantian status dan kepemimpinan PERJAN TVRI Stasiun Riau juga mengalami perkembangan salah satu dari bentuk perubahan tersebut terdapat dari penambahan jam siaran PERJAN TVRI Stasiun Pekanbaru yang sebelumnya berjumlah 1 jam 30 menit dalam 3 (tiga) kali selama satu minggu yaitu hari Senin, Rabu dan Jum'at menjadi setiap hari serta menambah program-program acara yang diproduksi oleh PERJAN TVRI Stasiun Pekanbaru (Suardi Camong, 2021). 


\section{Perkembangan Televisi Republik Indonesia (TVRI) Stasiun Riau Kepri 2002-2004}

Pada tahun 2002 PERJAN TVRI Stasiun Pekanbaru kembali berubah status dari Perusahaan Jawatan (PERJAN) menjadi Perseroan Terbatas (PT). Perubahan status ini berdasarkan Nomor 9 Tahun 2002 tentang pengalihan Bentuk Perusahaan Jawatan (PERJAN) Televisi Republik Indonesia menjadi Perusahaan Perseroan (Persero). Dalam pelaksanaannya PT TVRI (PERSERO) bertanggung jawab terhadap Kementerian Keuangan dan Kantor Menteri Negara BUMN. Berdasarkan Peraturan Pemerintah diatas adapun perubahan maksud dan tujuan dari Perusahaan Perseroan (PERSERO) TVRI adalah diharapkannya TVRI dapat menyelenggarakan kegiatan penyiaran televisi sesuai dengan prinsip-prinsip televisi publik yang independen, netral dan mandiri untuk meningkatkan dan mengembangkan sikap mental masyarakat Indonesia, meningkatkan pengetahuan dan kecerdasan masyarakat, serta lebih memperkokoh persatuan dan kesatuan bangsa dan menyelenggarakan usaha di bidang pertelevisian yang menghasilkan program siaran yang sehat dan bermutu tinggi sekaligus dapat memupuk keuntungan berdasarkan prinsip-prinsip pengelolaan perusahaan yang modern dan profesional.

pada saat itu PT. TVRI (PERSERO) Stasiun Riau terus mengembangkan program siaran dan mengingkatkan disiplin pegawai yang tujuannya adalah untuk memacu kreatifitas pegawai dalam meningkatkan mutu acara dari siaran di layar kaca, sehingga diharapkan dengan adanya peningkatan tersebut menjadikan siaran PT. TVRI (PERSERO) Stasiun Riau tetap mendapat

tempat dihati masyarakat yang menonton televisi dan bukan saja menjadi tontonan tetapi juga dapat menjadi tuntunan bagi masyarakat yang menonton 
TVRI pada saat itu. PT. TVRI (PERSERO) Stasiun Riau terus menambah jam siaran yang sebelumnya hanya bersiaran selama 1 Jam 30 Menit menjadi 2 Jam penayangan dimulai dari jam 15:00 WIB sampai dengan jam 17:00 WIB dan kembali meningkatkan siarannya di tahun yang sama yaitu tahun 2003 PT. TVRI (PERSERO) Stasiun Riau menjadi 3 Jam penayangan dari jam 16:00 sampai jam 19:00 WIB (Suardi Camong, 2021).

\section{Perkembangan Televisi Republik Indonesia (TVRI) Stasiun Riau Kepri 2005-2009}

Pada periode 2002-2004 TVRI Stasiun Riau Kepri masih berstatus sebagai Perusahaan Perseroan atau (PT) yang lebih dikenal dengan nama PT. TVRI (PERSERO) Stasiun Riau. Ditahun 2005 melalui Peraturan Pemerintah Nomor 13 Tahun 2005 tentang Lembaga Penyiaran Publik Televisi Republik Indonesia dan juga berdasarkan Undang-Undang No.32 Tahun 2002 tentang penyiaran. Lembaga Penyiaran Publik dimana dijelaskan bahwa Lembaga Penyiaran Publik adalah lembaga yang dibentuk oleh negara dengan badan hukum, yang bersifat secara independent, netral, tidak komersial dan berfungsi sebagai pemberi layanan kepada masyarakat yang ada di Indonesa. Sebagai lembaga

penyiaran Publik TVRI Stasiun Riau Kepri harus menyelenggarakan penyiaran yang harus berdifat netral, tidak komersial, dan berfungsi untuk memberikan layanan kepada khalayah ramai terutama masyarakat yang ada di Provinsi Riau dan Kepulauan Riau.

Pada tanggal 1 April 2007, program acara siaran LPP TVRI Stasiun Riau Kepri beralih teknologi menjadi sistem teknologi komputerisasi. Adapun untuk program siaran, TVRI Stasiun Riau Kepri mengacu pada pola acara dengan menyajikan acara-acara baru yang dikemas dalam bentuk yang 
menarik baik itu dalam bentuk informasi, pendidikan, budaya maupun hiburan yang dimana program-program tersebut menekankan kepada muatan lokal tentang budaya-budaya melayu. Dimana siaran program-program tersebut disiarkan secara langsung dari studio maupun melalui sistem play back dengan jumlah jam siaran yang bertambah menjadi 4 (empat) jam setiap harinya mulai dari jam 15.00 sampai 19.00 WIB (Muhyin, 2021).

\section{Perkembangan Televisi Republik Indonesia (TVRI) Stasiun Riau Kepri 2010-2018}

Perkembangan LPP TVRI Stasiun Riau Kepri dari tahun ketahun terus berkembang dengan adanya perkembangan tersebut membuat banyak hal-hal yang berubah kearah yang baru sesuai dengan perkembangan zaman. Salah satunya adalah perubahan sistem penyiaran dari sistem analog ke sistem digital di LPP TVRI Stasiun Riau Kepri. Dengan berubahnya sistem penyiaran di TVRI Stasiun Riau Kepri membuat terjadinya perubahan lama penayangan dan jumlah program dimana pada tanggal 9 Desember 2010 LPP TVRI Stasiun Riau Kepri sudah dapat bersiaran selama 9 Jam setiap harinya, dimulai pada pukul 13.00-22.00 WIB. Adapun siaran-siaran tersebut diproduksi harus berdasarkan aturan-aturan yang ada di dalam Peraturan Pemerintah Nomor 13 Tahun 2005 dan Undang-Undang No. 32 Tahun 2002. Dimana program siaran yang dibuat harus bersifat independen, netral, tidak komersial, dan berfungsi memberikan layanan untuk kepentingan masyarakat (Sri Pujiastuti, 2021).

Ditahun 2010 dikarenakan adanya beberapa hal yang terjadi, maka secara beransur-ansur aktvitas dari LPP TVRI Stasiun Riau Kepri yang awalnya berada di daerah Rumbai lebih tepatnya di Jalan di Jalan Pramuka 
Ujung No. 2, Lembahsari Kecamatan Rumbai Pesisir, Kota Pekanbaru di pindahkan ke Jalan Durian, Labuh Baru, Kecamatan Payung Sekaki, Kota Pekanbaru. Kantor baru LPP TVRI Stasiun Riau Kepri merupakan kantor stasiun transmisi atau pemancar dari LPP TVRI Stasiun Riau Kepri (Budi Rianto, 2021). Seiring berjalannya waktu dan setelah dipindahkannya semua aktivitas dari LPP TVRI Stasiun Riau Kepri ke Jalan Durian, hal ini juga berdampak dengan semakin berkembangnya LPP TVRI Stasiun Riau Kepri. Baik itu dengan bertambahnya sarana prasaran, bertambah canggihnya peralatan yang ada, bertambah banyaknya pegawai, dan beragamamnya program-program yang hadirkan kepada masyarakat salah satunya mengenai pembangunan yang di Provinsi Riau baik dari bidang pendidikan dan kebudayaan serta bidang sosial dan ekonomi.

Peranan Televisi Republik Indonesia (TVRI) stasiun Riau Kepri sebagai media massa dalam pembangunan di bidang sosial dan ekonomi

Jika dilihat dari fungsi TVRI sebagai sarana penerangan, pendidikan dan hiburan dari tahun ketahun sudah menampakan kemajuan. Hal ini sangat terlihat dari adanya perbaikan dan juga penambahan-penambahan baik itu sarana prasarana maupun program-program yang dihadirkan oleh TVRI Stasiun Riau, salah satunya adalah peranan TVRI Stasiun Riau Kepri sebagai media massa dalam pembangunan yang ada di Provinsi Riau yaitu di bidang sosial dan ekonomi. Sebagai media massa TVRI bertugas sebagai alat yang digunakan untuk menyebarluaskan informasi kekhalayak umum salah satunya mengenai pembangunan di Provinsi Riau. Oleh karena itu, untuk memenuhi peranan tersebut TVRI Stasiun Riau Kepri menghadirkan program- 
program yang menginformasikan mengenai pembangunan di bidang sosial dan ekonomi di Provinsi Riau.

sebagai media yang memberikan informasi dalam pembangunan di Provinsi Riau terdapat berbagai macam program yang berhubungan dan hal tersebut antara lain siaran Riau Cemerlang yang mana berisi dialog yang ditayangkan selama 1 (satu) jam yang disiarkan dari hari Senin sampai Jum'at dimana yang dibahas disini mengenai isu-isu yang sedang hangat termasuk dialog mengenai pembangunan di Provinsi Riau dimana sebagai narasumber merupakan orang--orang yang berkompeten di bidangnya. Selain itu ditahun 2018 terdapat program berita yang bernama Warta Riau yang dimana program ini berisi berita-berita hangat yang terjadi selain berita hangat juga terdapat berita-berita mengenai pembangunan yang ada di Provinsi Riau maupun Kepulauan Riau. Selain acara berita Warta Riau maupun dialog Riau Cemerlang terdapat juga program Inspirasi Indonesia yang mana merupakan program yang berisi mengenai sosok seseorang yang menginspirasi baik itu dari segi perjuangan dari 0 (nol) sampai akhir, yang diangkat dari hal-hal postif yang dimana memberikan dampak bagi orang lainnya baik di bidang ekonomi maupun di bidang sosial. Dari berbagai program yang dihadirkan TVRI Stasiun Riau Kepri sebagai media massa terlihat sangat berperan terhadap arus infromasi bagi masyarakat Provinsi Riau maupun di Provinsi Kepulauan Riau (Dermawan, 2021).

Peranan Televisi Republik Indonesia (TVRI) stasiun Riau Kepri sebagai media massa dalam pembangunan di bidang pendidikan dan kebudayaan 
Selain dalam menginformasikan mengenai pembangunan di bidang sosial dan ekonomi di Provinsi Riau, TVRI Stasiun Riau Kepri juga ikut dalam usaha memberikan informasi dalam pembangunan di bidang pendidikan dan kebudayaan, sebagaimana yang kita ketahui pembangunan di bidang pendidikan adalah suatu upaya mencerdaskan kehidupan bangsa dan meningkatkan kualitas manusia Indonesia dalam perwujudan masyarakat warganya mengembangkan diri baik berkenan dengan aspek jasmani maupun rohani berdasarkan Pancasila dan Undang-Undang Dasar 1945. Untuk menwujudkan pembangunan di bidang pendidikan TVRI Stasun Riau Kepri sebagai wadah penyebaran informasi berusaha menghadirkan berbagai macam program-program yang berhubungan dengan pembanguan di bidang pendidikan. Adapun beberapa program yang bertujuan untuk hal tersebut antara lain Akademi Dai Cilik (ADC) dan Lentera Hati. Disamping programprogram berita yang menyiarkan mengenai informasi di bidang pembangunan pendidikan yang ada di Provinsi Riau.

Selanjutnya, peran TVRI Stasiun Rau Kepri dalam pembangunan dibidang kebudayaan d Provinsi Riau sangatlah berperan. Hal ini sesuai dengan maksud dari pembangunuan dari bidang kebudayaan yaitu suatu proses meningkatkan atau mempertahankan kebiasaan yang ada pada masyarakat. Dimana TVRI Stasiun Riau Kepri mengambil peran sebagai media massa yang menyiarkan siaran mengenai kebudayaan tarutama yang ada di Provinsi Riau yaitu mengenai budaya melayu. Oleh karena itu, sebagai media massa TVRI Stasiun Riau berkontribusi dengan menghadirkan program yang membahas mengenai budaya melayu yang ada di Riau. Program tersebut 
adalah Rona Melayu, program ini berisi talkshow dengan menghadirkan budayawan atau orang yang ahli dalam bidang kebudayaan melayu di Riau (Evi Lauri Shanti, 2021).

\section{KESIMPULAN}

Era pertelevisian di Provinsi Riau sudah dimulai dari tahun 1977 dimana pada saat ini dibangunlah menara stasiun relai TVRI yang umumnya disebut stasiun pemancar tv pada tanggal 3 November 1998. Diresmikanlah TVRI Stasiun Riau Kepri yang pada saat itu bernama Stasiun Produksi Pekanbaru. Stasiun ini diresmikan oleh Bapak Mhd. Yunus yang saat itu menjabat sebagai Menteri Penerangan Republik Indonesia. Gedung TVRI Stasiun Produksi Pekanbaru terletak di Jalan Pramuka Ujung No. 2, Lembahsari Kecamatan

Rumbai Pesisir, Kota Pekanbaru. Perkembangan TVRI Stasiun Riau Kepri mulai terlihat pada 1999 dimana pada 1999 TVRI Stasiun Riau sudah dapat bersiaran secara lokal untuk pertama kali tepatnya pada bulan Januari. Sebagai media massa dalam bidang pembangunan di Provinsi Riau. TVRI Stasiun Riau Kepri bertugas sebagai alat yang digunakan untuk menyebarluaskan informasi kekhalayak umum salah satunya mengenai pembangunan di Provinsi Riau. Oleh karena itu, untuk memenuhi peranan tersebut TVRI Stasiun Riau Kepri menghadirkan program-program yang menginformasikan mengenai pembangunan baik di bidang sosial dan ekonomi serta pendidikan dan kebudayaan di Provinsi Riau. 


\section{DAFTAR PUSTAKA}

[1] Abdurahman, D. (2007). Metedologi Penelitian Sejarah. Yogyakarta: ArRuzz Media.

[2] Daulay, H. P., \& Pasa, N. (2016). Pendidikan Islam Dalam Lintas Sejarah Kajian Dari Zaman Pertumbuhan Sampai Kebangkitan. Jakarta:

Prenadamedia Group.

[3] Halim, S. (2019). Reportase Panduan Praktis Reportase untuk Media Televisi. Jakarta: Kencana.

[4] Herdiani, E. (2016). Metode Sejarah Dalam Penelitian Tari. Jurnal Ilmiah Seni Mangkalang, 33-45.

[5] Istanto, F. H. (1999). Peran Televisi Dalam Masyarakat Citraan Dewasa Ini Sejarah, Perkembangan, Dan Pengaruhnya. Nirmana, 95-108.

[6] Oetama, J. (2001). Pers Indonesia: Berkomunikasi dalam Masyarkat Tidak Tulus . Jakarta: Buku Kompas.

[7] Romli, K. (2016). Komunikasi Massa. Jakarta: PT Grasindo.

[8] Tahrun, Houtman, \& Nasir, M. (2019). Keterampilan Pers dan Jurnalistik Berwawasan Jender. Sleman, Yogyakarta: Deepublish.

[9] Wawancara Bapak Suardi Camong (Pegawai TVRI Stasiun Riau Kepri) pada tanggal 4 Februari 2021.

[10] Wawancara Ibu Sri Pujiastuti (Pegawai TVRI Stasiun Riau Kepri) pada tanggal 8 Februari 2021.

[11] Wawancara Bapak Muhyin (Pegawai TVRI Stasiun Riau Kepri) pada tanggal 8 Februari 2021. 
[12] Wawancara Ibu Evi Lauri Shanti (Pegawai TVRI Stasiun Riau Kepri) pada tanggal 16 Februari 2021.

[13] Wawancara Bapak Budi Rianto (Pegawai TVRI Stasiun Riau Kepri) pada tanggal 17 Februari 2021.

[14] Wawancara Bapak Darmawan (Pegawai TVRI Stasiun Riau Kepri) pada tanggal 17 Februari 2021. 